\title{
First study on parasites of Hemibrycon surinamensis (Characidae), a host from the eastern Amazon region
}

\author{
Primeiro estudo sobre parasitos de Hemibrycon surinamensis (Characidae), \\ um hospedeiro na Amazônia oriental
}

\author{
Maria Danielle Figueiredo Guimarães Hoshino ${ }^{1}$ Érico Melo Hoshino² ${ }^{\text {; Marcos Tavares-Dias }}{ }^{1,3 *}$ \\ ${ }^{1}$ Postgraduate Program on Tropical Biodiversity, Universidade Federal do Amapá - Unifap, Macapá, AP, Brazil \\ ${ }^{2}$ Fishery Engineering Course, Universidade Estadual do Amapá - UEAP, Macapá, AP, Brazil \\ ${ }^{3}$ Aquiculture and Fishery Laboratory, Embrapa Amapá, Macapá, AP, Brazil
}

Received April 2, 2014

Accepted June 9, 2014

\begin{abstract}
This study was the first investigation of communities and infracommunities of parasites of Hemibrycon surinamensis. All the fish collected in a tributary of the Amazon river were parasitized by one or more parasite species. The Brillouin diversity index $(H B)$ was $0.46 \pm 0.28$ and the mean species richness was $3.5 \pm 1.2$ parasites per host. A total of 14,734 parasites were collected, including Ichthyophthirius multifliis and Piscinoodinium pillulare (Protozoa); Jainus hexops and Tereancistrum sp. (Monogenoidea); Ergasilus turucuyus and Argulus sp. (Crustacea); metacercariae of Derogenidae gen. sp.; metacercariae and adults of Genarchella genarchella (Digenea); and Cucullanus larvae and Contracaecum larvae (Nematoda). The dominant parasite was I. multifiliis, followed by P. pillulare. The parasites showed aggregated dispersion, except for E. turucuyus, which had random dispersion. The condition factor (Kn) indicated that the parasitism levels had not affected host body condition. The high levels of infection observed were due to host behavior, and this was discussed. This was the first report of I. multifiliis, P. pillulare, Argulus sp., E. turucuyus, G. genarchella, J. hexops and Tereancistrum sp. in H. surinamensis, and it expanded the occurrence of E. turucuyus and G. genarchella to the eastern Amazon region.
\end{abstract}

Keywords: Brazil, diversity, ectoparasites, freshwater fish, infracommunity.

\section{Resumo}

Este estudo é a primeira investigação sobre as comunidades e infracomunidades de parasitos de Hemibrycon surinamensis. Todos os peixes coletados no tributário do Rio Amazonas estavam parasitados por uma ou mais espécies de parasitos. O índice de diversidade de Brillouin $(H B)$ foi $0,46 \pm 0,28$ e a riqueza de espécies foi 3,5 $\pm 1,2$ parasitos por hospedeiro. Foram coletados 14.734 parasitos, entre Ichthyophthirius multifiliis, Piscinoodinium pillulare (Protozoa), Jainus hexops e Tereancistrum sp. (Monogenoidea), Ergasilus turucuyus, Argulus sp. (Crustacea), metacercárias de Derogenidae gen. sp., metacercárias e adultos de Genarchella genarchella (Trematoda), larvas de Cucullanus e larvas de Contracaecum (Nematoda). A dominância foi de I. multifiliis, seguida por $P$. pillulare. Os parasitos mostraram dispersão agregada, exceto E. turucuyus, que teve dispersão aleatória. O fator de condição $(\mathrm{Kn})$ indicou que os níveis de parasitismo não afetaram as condiçóes corporais dos hospedeiros. Foram discutidos os elevados níveis de infecção os quais estão associados ao comportamento do hospedeiro. Este é o primeiro relato de I. multifiliis, P. pillulare, Argulus sp., E. turucuyus, G. genarchella, J. hexops e Tereancistrum sp. para H. surinamensis, expandindo a ocorrência de E. turucuyus e G. genarchella para a Amazônia oriental.

Palavras-chave: Brasil, diversidade, ectoparasitos, peixe de água doce, infracomunidade.

*Corresponding author: Marcos Tavares-Dias, Embrapa Amapá, Rodovia Juscelino Kubitschek, km 5, 2600, CEP 68903-419, Macapá, AP, Brazil, e-mail: marcos.tavares@embrapa.br 


\section{Introduction}

The Neotropical freshwater fish fauna has the highest diversity and species richness in the world (AZEVEDO, 2010). The order Characiformes is considered to be one of the most representative in freshwater environments of Brazil, and the family Characidae is the largest within this order of Neotropical fish. The family Characidae includes numerous species of small, medium and large size (REIS et al., 2003). Among the small-sized fish is the genus Hemibrycon, which has 32 species distributed in Panama, the Caribbean, Venezuela, Trinidad and Tobago, Brazil, Bolivia, Ecuador and Peru (BERTACO; MALABARBA, 2010; FROESE; PAULY, 2013).

Hemibrycon surinamensis Géry, 1962, the species that forms the focus of the present study, is only distributed in South America: in coastal basins of French Guiana and Suriname, and in the basins of the Tapajós, Tocantins and Xingu rivers in Brazil (REIS et al., 2003; BERTACO; MALABARBA, 2010; FROESE; PAULY, 2013). These fish have benthopelagic behavior; the males reach a maximum length of $8.0 \mathrm{~cm}$ and the females, $9.1 \mathrm{~cm}$ (FROESE; PAULY, 2013). In the eastern Amazon region, $H$. surinamensis is known as "matupiri" and is present in the basin of the Igarapé Fortaleza. This basin is located in the estuarine coastal sector, which is characterized by having extensive river-floodplain systems. These are physical river systems that fill up with accumulations of detritus, sedimentary material and organic matter, and are drained by freshwater and connected to a main water course. These systems are influenced by rainfall in the Amazon region and also by the daily tides of the Amazon River (TAKIYAMA et al., 2004). This unique ecosystem is rich in aquatic vegetation, especially macrophytes (THOMAZ et al., 2004), and therefore its lowland areas are widely used for shelter and food by many fish, including $H$. surinamensis.

Studies on the biology of $H$. surinamensis are still scarce, especially regarding its parasites and feeding habits. However, studies on parasites should be directed not only towards fish of economic importance, but also towards others, given the biological importance of fish in food chains (EIRAS et al., 2011). Several factors influence the diversity and structure of parasite infracommunities, such as the habitat, age, size and life history of the host fish, particularly regarding their trophic category and migratory capacity (GUIDELLI et al., 2003; TAVARESDIAS et al., 2010; AZEVEDO et al., 2011; BELLAY et al., 2012). Knowledge about parasite infracommunities and their relationships with host fish is of great importance, since these parasites also play a key role in ecosystems by regulating the abundance or density of natural fish populations, thus stabilizing food chains and host community structures (ZRNČIĆ et al., 2009; TAKEMOTO et al, 2009; AZEVEDO et al., 2011). In this way, the present study was the first investigation on several aspects of parasites of $H$. surinamensis from a tributary of the Amazon river, state of Amapá, Brazil.

\section{Materials and Methods}

\section{Fish and sampling site}

From October to November 2011, 93 specimens of Hemibrycon surinamensis $(11.1 \pm 0.7 \mathrm{~cm}$ and $24.5 \pm 3.7 \mathrm{~g})$ were collected in the basin of the Igarapé Fortaleza (002'31.4” S, 05105'52.18” W), Macapá (state of Amapá, Brazil), for parasitological analysis. The fish were collected using gill nets of different mesh sizes (ICMBio License: 23276-1) and were immediately transferred on ice to the Aquatic Organism Health Laboratory of Embrapa Amapá (in Macapá), for parasitological analysis.

\section{Procedures for parasite collection and analysis}

The fish collected were weighed $(\mathrm{g})$ and measured for total length (cm). Each individual was macroscopically evaluated regarding body surface, mouth, eyes, opercula and gills. The gills were removed to collect ectoparasites. The gastrointestinal tract was removed and examined in order to collect endoparasites. All the parasites were collected, fixed, stained for identification (EIRAS et al., 2006) and quantified (TAVARES-DIAS et al., 2001). The parasitological terms adopted were those recommended by ROHDE et al. (1995) and BUSH et al. (1997). Voucher specimens were deposited at the Scientific and Technological Research Institute of the State of Amapá (Instituto de Pesquisas Científicas e Tecnológicas do Estado do Amapá, IEPA), in the Scientific Collection Curation Office for the Fauna of Amapá (Curadoria das Coleções Científicas, Fauna do Amapá, CCFA), under accession number IEPA 012-018-P.

The Brillouin index $(H B)$, evenness $(E)$, Berger-Parker dominance index $(d)$ and species richness (MAGURRAN, 2004) were calculated for the parasite component community, by using the Diversity software (Pisces Conservation Ltd., UK). The dispersion index (ID) and the discrepancy index (D) were calculated using the Quantitative Parasitology 3.0 software, in order to detect the distribution pattern of each parasite infracommunity (RÓZSA et al., 2000 ) in species with prevalence $\geq 10 \%$. The significance of ID for each parasite species was tested using $d$-statistics (LUDWIG; REYNOLDS, 1988).

Data on body weight $(\mathrm{g})$ and total length $(\mathrm{cm})$ were used to calculate the relative condition factor $(\mathrm{Kn})$ of the fish (LE CREN, 1951), which was compared with the standard value $(\mathrm{Kn}=1.0)$ by means of the $t$ test. The Pearson correlation coefficient ( $r$ ) was used to check for correlations between host length and the Brillouin index $(H B)$ and parasite abundance (ZAR, 2010), using the BioEstat 5.0 software.

\section{Results}

All the fish examined were parasitized by one or more parasite species. A total of 14,734 parasites were collected and these included Ichthyophthirius multifiliis Fouquet, 1876 (Ciliophora); Piscinoodinium pillulare Schäperclaus, 1954, Lom 1981 (Dinoflagellida); Jainus hexops Kritsky \& Leiby, 1972; Tereancistrum Kritsky, Thatcher \& Kayton, 1980 (Dactylogyridae); 
Ergasilus turucuyus Malta \& Varella, 1996 (Ergasilidae); Argulus Muller, 1785 (Argulidae); metacercariae of Derogenidae gen. sp.; metacercariae and adults of Genarchella genarchella Kohn \& Fernandes (1988) (Derogenidae); larvae of Cucullanus Muller, 1777 (Cucullanidae) and larvae of Contracaecum Railliet \& Henry, 1912 (Anisakidae). Ectoparasite species predominated and I. multifiliis was the dominant parasite species, but endoparasite species were also found (Table 1 ). The parasites presented aggregated dispersion, except for E. turucuyus, which had random dispersion (Table 2).

The Brillouin diversity index $(H B)$ was $0.46 \pm 0.28$, the evenness $(E)$ was $0.24 \pm 0.15$, the dominance $(d)$ was $0.78 \pm 0.19$ and the mean species richness was low $(3.5 \pm 1.2$ parasites per host). The $H B$ did not show any significant correlation $(\mathrm{r}=0.121, \mathrm{p}=0.247)$ with total host length. Hosts parasitized by three to four parasite species predominated (Figure 1).

The condition factor $(\mathrm{Kn}=1.000 \pm 0.092, \mathrm{t}=0.023, \mathrm{p}=0.982)$ of the parasitized fish did not differ from the standard value $(\mathrm{Kn}=1.0)$, thus indicating that the parasitism had not impaired host body condition. The total host length only showed a positive correlation with the abundance of Tereancistrum sp. in the gills of $H$. surinamensis (Figure 2).

\section{Discussion}

The parasite community of $H$. surinamensis showed high diversity, consisting of two Protista, two Monogenoidea, two Crustacea, two Digenea and two Nematoda. The highest richness of ectoparasites (seven species) reflects environmental conditions that were favorable to their transmission, because they did not need intermediate hosts. The low richness of endoparasites may be related to the living habits of this host, which occupies the second trophic level in the food chain. Infection by I. multifiliis, P. pillulare, J. hexops, Tereancistrum sp., metacercariae and adults of G. genarchella and Contracaecum sp. larvae presented aggregated dispersion, which is a common pattern among freshwater fish (GUIDELLI et al., 2003). Nevertheless, E. turucuyus showed random dispersion in the gills of $H$. surinamensis, which is typical of parasites with moderate or high pathogenicity, since these parasites regulate the population density of hosts, while overdispersion of parasites tends to stabilize the host-parasite relationship (MOLLER, 2006). Meanwhile, besides presenting high pathogenicity (MALTA; VARELLA, 1996), E. turucuyus appears to have presented reduced ability to colonize $H$. surinamensis due to competition with other species of parasites that were overdispersed in the gills.

Only one specimen of Argulus sp. was collected from the gills of $H$. surinamensis in the basin of the Igarapé Fortaleza, eastern Amazon region. Argulus pestifer, Argulus multicolor, Argulus juparanaensis and Argulus amazonicus have frequently been observed in different fish species in the Brazilian Amazon region (MALTA, 1998). Ergasilus turucuyus, another crustacean parasitizing the gills of $H$. surinamensis, presented low infection levels (prevalence $=10.8 \%$ and mean intensity $=1.1$ ), in comparison with Acestrorhynchus falcatus and Acestrorhynchus falcirostris (prevalence $=27.0 \%$ and mean intensity $=11$ ) in the Pacaás Novos river in the western Amazon region (MALTA; VARELLA, 1996). Because only these Characiformes hosts were infected by E. turucuyus, it seems that these copepods have higher specificity than other species of crustaceans.

Table 1. Parasites of Hemibrycon surinamensis in the Igarapé Fortaleza basin, eastern Amazon region, Brazil. FE: number of fish examined; FP: number of fish parasitized; P: prevalence; MI: mean intensity; MA: mean abundance; TNP: total number of parasites; IS: infection site.

\begin{tabular}{|c|c|c|c|c|c|c|}
\hline Parasites & FE/FP & $\mathbf{P}(\%)$ & MI (Range) & $\mathrm{MA} \pm \mathrm{SD}$ & TNP & IS \\
\hline Ichthyophthirius multifiliis & $93 / 61$ & 65.6 & $197.1(15-1890)$ & $129.3 \pm 246.4$ & 12,025 & Gills \\
\hline Piscinoodinium pillulare & $93 / 16$ & 17.2 & $104.5(15-450)$ & $18.0 \pm 61.9$ & 1672 & Gills \\
\hline Tereancistrum sp. & $93 / 87$ & 93.5 & $6.4(1-25)$ & $6.0 \pm 5.3$ & 556 & Gills \\
\hline Jainus hexops & $93 / 66$ & 71.0 & $3.9(1-19)$ & $2.7 \pm 3.4$ & 255 & Gills \\
\hline Ergasilus turucuyus & $93 / 10$ & 10.8 & $1.1(1-2)$ & $0.1 \pm 0.4$ & 11 & Gills \\
\hline Argulus sp. & $93 / 1$ & 1.1 & 1.0 & 0.01 & 1 & Gills \\
\hline Derogenidae gen. sp. (metacercariae) & $93 / 62$ & 66.7 & $2.8(1-24)$ & $1.9 \pm 3.0$ & 176 & Gills \\
\hline Genarchella genarchella adults & $93 / 5$ & 5.4 & $1.2(1-2)$ & $0.3 \pm 0.3$ & 6 & Intestine \\
\hline Cucullanus sp. (larvae) & $93 / 6$ & 6.5 & $1.2(1-2)$ & $0.08 \pm 0.3$ & 7 & Intestine \\
\hline Contracaecum sp. (larvae) & $93 / 14$ & 15.1 & $1.8(1-7)$ & $0.06 \pm 1$ & 25 & Intestine \\
\hline
\end{tabular}

Table 2. Dispersion index (DI), $d$-statistic, discrepancy index (D) and relative dominance (RD) for main parasites of Hemibrycon surinamensis in the Igarapé Fortaleza basin, eastern Amazon region, Brazil.

\begin{tabular}{lcccc}
\hline \multicolumn{1}{c}{ Parasites } & DI & $d$ & D & RD \\
\hline Ichthyophthirius multifiliis & 8.182 & 25.3 & 0.560 & 0.816 \\
Piscinoodinium pillulare & 6.333 & 20.6 & 0.347 & 0.113 \\
Tereancistrum sp. & 1.801 & 4.67 & 0.347 & 0.038 \\
Jainus hexops & 2.558 & 8.17 & 0.540 & 0.017 \\
Ergasilus turucuyus & 1.075 & 0.53 & 0.892 & 0.0007 \\
Derogenidae gen sp. & 1.938 & 5.35 & 0.560 & 0.012 \\
Contracaecum sp. & 1.443 & 2.77 & 0.870 & 0.002 \\
\hline
\end{tabular}




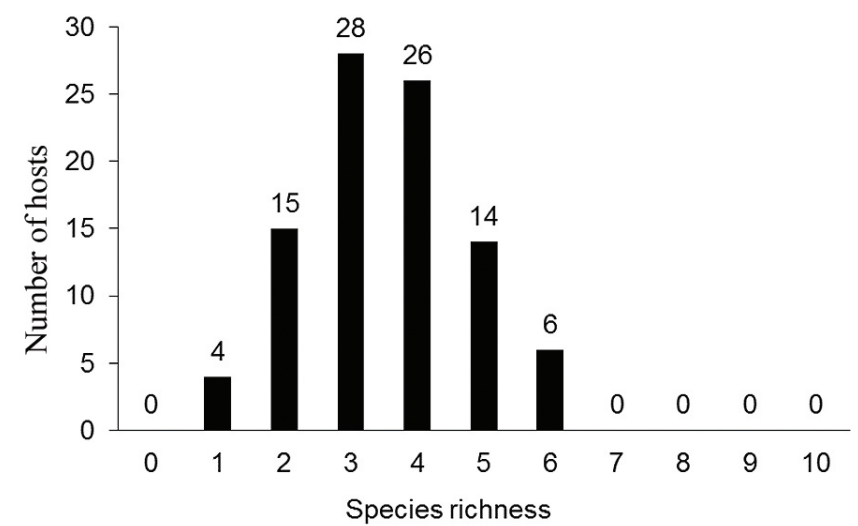

Figure 1. Species richness of parasites in Hemibrycon surinamensis in the Igarapé Fortaleza basin, eastern Amazon region, Brazil.

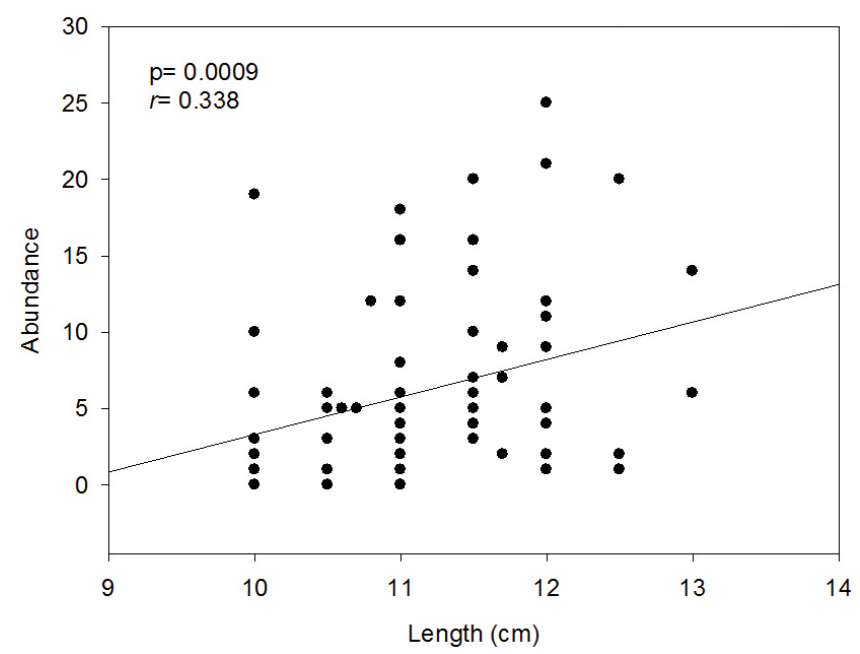

Figure 2. Correlation between the abundance of Tereancistrum sp. and total length of Hemibrycon surinamensis in the Igarapé Fortaleza basin, eastern Amazon region, Brazil.

Ichthyophthirius multifliis was the dominant parasite in $H$. surinamensis, followed by $P$. pillulare, but infections by these protozoa occurred more frequently than in Carnigiella martae (TAVARES-DIAS et al., 2010), Cobitis elongatoides and C. elongatus in natural environments (ZRNČIĆ et al., 2009). However, neither of these parasites presents specificity, and high levels of parasitism are more frequent in lentic environments, such as rearing tanks (ZRNČIĆ et al., 2009; TAVARES-DIAS et al., 2010). Therefore, these high infection levels in $H$. surinamensis were influenced by the aggregating behavior of those hosts, which in general live under the macrophytes, where they spend most of their time on feeding.

In the gills of $H$. surinamensis, the level of infection by Tereancistrum sp. was relatively higher than by J. hexops. However, the prevalence of these monogenoidean species was higher than that of Tereancistrum arcuatus and Jainus iocensins in Salminus brasiliensis in the Paraná river, Brazil (COHEN et al., 2012). In addition, the abundance of Tereancistrum sp. increased with the length of $H$. surinamensis, thus indicating that accumulation occurs over the period of host growth. Similarly, in Geophagus brasiliensis, the abundance of $S$. frequens was also positively correlated with its length (BELLAY et al., 2012). Six species of Tereancistrum are known and they parasitize fish of different host families in Brazil. There were also two species Bryconidae, one of Anostomidae and three of Prochilodontidae (COHEN et al., 2013). Jainus hexops was originally described in the gills of Astyanax fasciatus (Characidae) in Costa Rica (KRITSKY and LEIBY, 1972), and it has also been reported parasitizing Moenkhausia sanctaeflomenae (Characidae) in the Paraná river (TAKEMOTO et al., 2009) in Brazil. Therefore, the present report provided the third record of J. hexops, which also occurred in other Characidae species.

Metacercariae of Derogenidae, probably species of the genus Genarchella, were found at high levels of infection in the gills of $H$. surinamensis, in comparison with parasitism by metacercariae and adults of $G$. genarchella in the intestine of this same host. Kohn et al. (2011) also reported infection by $G$. genarchella in two specimens of Pimelodus ornatus (Siluriformes) in the Itaipu reservoir, state of Paraná. This digenean species has mollusks and Cypriniformes as intermediate hosts, and Characiformes and Siluriformes as definitive hosts (MARTORELLI, 1989; LEFEBVRE; POULIN, 2005). Thus, in the Igarapé Fortaleza basin, the Characiforme $H$. surinamensis may still be infected by this digenean through ingestion of mollusks (LEFEBVRE; POULIN, 2005) and/or direct contact with larval forms (cercariae) in the aquatic environment (MORLEY, 2012).

Larvae of Contracaecum sp. and Cucullanus sp. were detected at low infection levels in the intestine of $H$. surinamensis, as expected, since omnivorous fish have low risk of infection in comparison with carnivorous fish, which are at the top of the food chain. Low parasitism by Contracaecum sp. larvae has also been reported in relation to Metynnis lippincottianus, an omnivorous fish in the Paraná river basin (MOREIRA et al., 2009), as well as by Cucullanus zungaro in Hemisorubim platyrhynchos in the Baía river (GUIDELLI et al., 2003). The intermediate hosts of these nematodes are microcrustaceans (MORAVEC, 1998; MOREIRA et al., 2009), and $H$. surinamensis is the second intermediate or paratenic host for Cucullanus sp. In Brazil, 24 species of the genus Cucullanus mainly parasitizes Siluriforme species of freshwater and marine ecosystems, but a few species are known to have Characiformes hosts, including C. brevispiculus, C. mogi and C. pinnai pinnai (LUQUE et al., 2011).

In the Igarapé Fortaleza basin, $H$. surinamensis feeds on mollusks and microcrustaceans. Thus, it is an omnivorous fish with an intermediate position in the food chain of the fish community, possibly serving as a forage species for predatory fish that are the intermediate hosts of Contracaecum sp., an anisakid for which the definitive hosts are fish-eating birds and fish-eating aquatic mammals. This was the first report of these parasite species in $H$. surinamensis, and it expanded the occurrence of E. turucuyus and G. genarchella to the eastern Amazon region.

\section{Acknowledgements}

Marcos Tavares-Dias was supported by a research fellowship from the National Council for Scientific and Technological Development (Conselho Nacional de Pesquisa e Desenvolvimento Tecnológico, CNPq), Brazil. 


\section{References}

Azevedo MA. Reproductive characteristics of characid fish species (Teleostei, Characiformes) and their relationship with body size and phylogeny. Iheringia Sér Zool. 2010; 100(4): 469-482. http://dx.doi. org/10.1590/S0073-47212010000400020.

Azevedo RK, Abdallah VD, Luque JL. Biodiversity of fish parasites from Guandu river, Southeastern Brazil: an ecological approach. Neotrop Helminthol. 2011; 5(2): 185-199.

Bellay S, Ueda BH, Takemoto RM, Lizama MLAP, Pavanelli GC. Fauna parasitária de Geophagus brasiliensis (Perciformes: Cichlidae) em reservatórios do estado do Paraná, Brasil. Rev Bras Biociênc. 2012; 10(1): 74-78.

Bertaco VA, Malabarba LRA. A review of the Cis-Andean species of Hemibrycon Günther (Teleostei: Characiformes: Characidae: Stevardiinae), with description of two new species. Neotrop Ichthyol. 2010; 8(4): 737-770. http://dx.doi.org/10.1590/S1679-62252010000400005.

Bush AO, Lafferty KD, Lotz JM, Shostak AW. Parasitology meets ecology on its own terms: Margolis et al. revisited. J Parasitol. 1997; 83(4): 575583. http://dx.doi.org/10.2307/3284227. PMid:9267395

Cohen SC, Kohn A, Boeger WA. Neotropical Monogenoidea. 57. Nine new species of Dactylogyridae (Monogenoidea) from the gill of Salminus brasiliensis (Characidae, Characiformes) from the Paraná river, State of Paraná, Brazil. Zootaxa. 2012; 3049: 57-68.

Cohen SC, Justo MCN, Kohn A. South American Monogenoidea parasites offishes, amphibians and reptiles. Rio de Janeiro: Oficina de Livros; 2013.

Eiras JC, Takemoto RM, Pavanelli GC, Adriano EA. About the biodiversity of parasites of freshwater fish from Brazil. Bull Eur Assoc Fish Pathol. 2011; 31(4): 161-168.

Eiras JC, Takemoto RM, Pavanelli GC. Métodos de estudo e técnicas laboratoriais em parasitologia de peixes. Maringá: Editora UEM; 2006.

Froese R, Pauly D, editors. FishBase. version (04/2013) [online]. Available from: www.fishbase.org.

Guidelli GM, Isaac A, Takemoto RM, Pavanelli GC. Endoparasite infracommunities of Hemisorubim platyrhynchos (Valenciennes, 1840) (Pisces: Pimelodidae) of the Baía River, Upper Parana River floodplain, Brazil: specific composition and ecological aspects. Braz J Biol. 2003; 63(2): 261-268. http://dx.doi.org/10.1590/S151969842003000200011. PMid:14509848

Kohn A, Moravec F, Cohen SC, Canzi C, Takemoto RM, Fernandes BMM. Helminths of freshwater fishes in the reservoir of the Hydroelectric Power Station of Itaipu, Paraná, Brazil. Check List. 201 1; 7(5): 681-690.

Kritsky DC, Leiby PD. Dactylogyridae (Monogenea) from the freshwater fish, Astyanax fasciatus (Cuvier), in Costa Rica, with descriptions of Jainus hexops sp. n., Urocleidoides costaricensis, and U. heteroancistrium combs, n. Proc Helm Soc Wash. 1972; 39(2): 227-230.

Le Cren ED. The length-weight relationship and seasonal cycle in gonad weight and condition in the perch (Perca fluviatilis). J Anim Ecol. 1951; 20(2): 201-219. http://dx.doi.org/10.2307/1540.

Lefebvre F, Poulin R. Progenesis in digenean trematodes: a taxonomic and synthetic overview of species reproducing in their second intermediate hosts. Parasitology. 2005; 130(6): 587-605. http://dx.doi.org/10.1017/ S0031182004007103. PMid:15977895

Ludwig JA, Reynolds JF. Statistical ecology: a primer on methods and computing. New York: Wiley-Interscience Pub.; 1988.

Luque JL, Aguiar JC, Vieira FM, Gibson DI, Portes-Santos C. Checklist of Nematoda associated with the fishes of Brazil. Zootaxa. 2011; 3082: $1-88$.

Magurran AE. Measuring biological diversity. Oxford: Blackwell Science; 2004 .
Malta JCO, Varella AMB. Ergasilus turucuyus sp. n. (Copepoda: Ergasilidae) das brânquias de Acestrorhynchus falcatus (Bloch, 1794) e A. falcirostris (Cuvier, 1819) (Characiformes, Characidae) da Amazônia Brasileira. Acta Amazon. 1996; 26(2): 69-76.

Malta JC. Maxillopoda. Branchyura. In: Young PS. Catalogue of crustacea of Brazil. Rio de Janeiro: Museu Nacional; 1998. p. 67-74.

Martorelli SR. Estudios parasitologicos en biotopos lénticos de la República Argentina. V. Dessarollo del ciclo biológico monoxeno de la metacercaria progénetica de Gernachella genarchella Travassos 1928 (Digenea: Hemiuridae) parasita de Littoridina parchappei (Mollusca: Hidrobiidae). Rev Mus Cienc Nat Zool. 1989; 14(157): 109-117.

Moller AP. Parasitism and the regulation oh host populations. In: Thomas F, Renaud F, Guégan JF. Parasitism and ecosystems. New York: Oxford University Press; 2006. p. 43-53.

Moravec F. Nematodes of freshwater fishes of the Neotropical region. Prague: Academia; 1998.

Moreira LHA, Takemoto RM, Yamada FH, Ceschini TL, Pavanelli GC. Ecological aspects of metazoan endoparasites of Metynnis lippincottianus (Cope, 1870) (Characidae) from upper Paraná river floodplain, Brazil. Helminthologia. 2009; 46(4): 214-219. http://dx.doi.org/10.2478/ s11687-009-0040-9.

Morley NJ. Cercariae (Platyhelmintes: Trematoda) as neglected components of zooplankton communities in freshwater habitats. Hydrobiologia. 2012; 691(1): 7-19. http://dx.doi.org/10.1007/s10750012-1029-9.

Reis RE, Kullander SO, Ferraris CJJR. Check list of the freshwater fishes of South and Central America. Porto Alegre: EDIPUCRS; 2003.

Rohde K, Hayward C, Heap M. Aspects of the ecology of metazoan ectoparasites of marine fishes. Int J Parasitol. 1995;25(8): 945-970. http:// dx.doi.org/10.1016/0020-7519(95)00015-T. PMid:8550295

Rózsa L, Reiczigel J, Majoros G. Quantifying parasites in samples of hosts. J Parasitol. 2000; 86(2): 228-232. http://dx.doi.org/10.1645/00223395(2000)086[0228:QPISOH]2.0.CO;2. PMid:10780537

Takemoto RM, Pavanelli GC, Lizama MAP, Lacerda ACF, Yamada FH, Moreira LHA, et al. Diversity of parasites of fish from the Upper Paraná River floodplain, Brazil. Braz J Biol. 2009; 69(2, Suppl): 691-705. http:// dx.doi.org/10.1590/S1519-69842009000300023. PMid:19738975

Tavares-Dias M, Lemos JRG, Martins ML. Parasitic fauna of eight species of ornamental freshwater fish species from the middle Negro River in the Brazilian Amazon Region. Rev Bras Parasitol Vet. 2010; 19(2): 103-107. http://dx.doi.org/10.4322/rbpv.01902007. PMid:20624347

Tavares-Dias M, Martins ML, Moraes FR. Fauna parasitária de peixes oriundos de "pesque-pague" do município de Franca, São Paulo, Brasil. I. Protozoários. Rev Bras Zool. 2001; 18(S1): 67-79. http://dx.doi. org/10.1590/S0101-81752001000500005.

Takiyama LR, Silva AQ, Costa WJP, Nascimento HS. Qualidade das águas das ressacas das bacias do Igarapé da Fortaleza e do Rio Curiaú. In: Takiyama LR, Silva AQ. Diagnóstico das ressacas do estado do Amapá: bacias do Igarapé da Fortaleza e Rio Curiaú. Macapá: CPAQ/IEPA e DGEO/SEMA; 2004. p. 81-104.

Thomaz DO, Costa-Neto SV, Tostes LCL. Inventário florístico das ressacas das bacias do Igarapé da Fortaleza e do Rio Curiaú. In: Takiyama LR, Silva AQ. Diagnóstico das ressacas do Estado do Amapá: bacias do Igarapé da Fortaleza e Rio Curiaú. Macapá: CPAQ/IEPA e DGEO/ SEMA; 2004. p. 1-22.

Zar JH. Biostatistical analysis. 5. ed. New Jersey: Prentice Hall; 2010.

Zrnčić S, Oraic D, Sostaric B, Caleta M, Bulj I, Zanella D, et al. Occurrence of parasites in Cobitidae from Croatian rivers draining into two different watersheds. J Appl Ichthyology. 2009; 25(4): 447-450. http:// dx.doi.org/10.1111/j.1439-0426.2009.01192.x 